nature

immunology

\title{
The final push?
}

\section{Over 20 years ago, the Global Polio Eradication Initiative was launched. Today, polio is still endemic in four countries.}

W ith great fanfare, the World Health Assembly launched the Global Polio Eradication Initiative (GPEI) just over 20 years ago. In what was described as a "magnificent gift from the 20th century to future generations of children," public health officials and volunteers committed themselves to ridding the planet of polio by the year 2000. Unfortunately, there are still new cases of infection in 2009. Although worldwide cases of polio have fallen from 350,000 in 1988 to under 2,000 in 2008, some experts question whether eradication will ever be possible. Many elements are conspiring against the efforts to eliminate disease, including the present political and economic crisis.

By 2001, it almost seemed that the battle against polio had been wonworldwide cases fell to an all-time low of 791. Poliomyelitis type II had been completely eradicated by 1999 . However, since 2003 the initiative has suffered several setbacks. In Nigeria, rumors began circulating that the polio vaccine contained the AIDS virus and was part of a Western plot to sterilize Muslim girls. The vaccine was described as "tainted by evildoers from America" and was "America's revenge for September 11th." As a result, the Nigerian government halted the vaccination campaign until the vaccine could be proven safe. As a consequence, 18 formerly polio-free countries suffered outbreaks traceable to Nigeria. A few countries, such as Sudan, are still struggling to regain their polio-free status.

At present, polio is endemic in four countries: Nigeria, Afghanistan, Pakistan and India. In 2007, an intensified eradication effort was launched by the GPEI to circumvent the remaining technical, financial and operational barriers that were preventing polio eradication in these countries (http://www.polioeradication.org/content/publications/ PolioStrategicPlan09-13_Framework.pdf). By mid-2008, two independent World Health Organization (WHO) advisory bodies concluded that the intensified efforts could overcome these challenges, and consequently a new Strategic Plan 2009-2013 has been endorsed. This 5-year plan combines proven eradication strategies with recently developed tools and tactics, including improving the efficacy of the vaccine. But even with a new strategic plan in place, is it realistic to expect a poliofree world by 2013 ?

The GPEI will need to overcome many obstacles, not least the political instability of many regions in the polio-endemic countries. Afghanistan and Pakistan will probably pose the greatest challenge. Because of successful vaccine drives, no cases of polio have been reported in the relatively peaceful northern provinces of Afghanistan, but the conflictridden south and southeastern provinces still suffer recurrent outbreaks. Access of aid workers to vulnerable communities in these areas has been increasingly limited. Many aid workers have been killed, abducted or threatened by criminal gangs and Taliban insurgents in recent years, according to the Afghanistan NGO Safety Office. Only a few months ago, a day of tranquility organized by the United Nations Assistance Mission in Afghanistan to enable immunizations in remote areas was cancelled by the WHO after two Afghan doctors were killed by a suicide car bombing caused by the Taliban.

Pakistan has also become increasingly unstable. The Taliban and Al-Qaeda resurgence in the North-West Frontier Province of Pakistan is allowing the virus to cross borders between the two countries unimpeded. Cases of polio have exploded in Pakistan, causing outbreaks in previously polio-free areas. In 2007, the cleric Mufti Khalid Shah declared a fatwa on employees of the United Nations, WHO and all other foreign organizations in 2007, and aid workers in Bannu were sent a 500-rupee note with a letter stating they could either stop or buy their own coffin.

Cultural differences also present problems for the vaccine program in these regions. Finding sufficient numbers of women to join the vaccination team has been difficult. However, the participation of women is essential, as by tradition only women can enter a Muslim household when the husband is away, and women with children are usually better at persuading other mothers to vaccinate. The GPEI must also persuade people that the vaccine is safe, improve poor sanitation that can interfere with uptake of the oral vaccine, and offset fatigue that can set in among volunteers, donors and the general populace. It only takes one unvaccinated child to trigger a new epidemic.

Fortunately, fatigue has not affected the organizers of the eradication movement. In January 2009, the Bill \& Melinda Gates Foundation, Rotary International and the governments of the UK and Germany pledged US\$630 million over 5 years for a massive final push to rid humanity of this scourge. But this may not be enough. Heidemarie Wieczorek-Zeul, the German Federal Minister for Economic Cooperation and Development, estimated that even with the new injection of funds, the global initiative is still some US\$340 million short of its budget for 2009-2010. Given that funding agencies and charities, including the Gates Foundation, are having to prune grant growth because of the recession, these are uncertain times for the eradication program.

Nevertheless, there are many reasons to be optimistic. The government in Nigeria is now firmly behind the GPEI, and Muslim clerics who initially shunned the vaccine program are now actively campaigning for acceptance of the polio vaccine. In March, President Barack Obama announced the mobilization of more troops in Afghanistan to "disrupt, dismantle and defeat" the terrorist Al-Qaeda network in Afghanistan and neighboring Pakistan. Although the final push for eradication will be costly and difficult, it certainly will not compare with the costs the world would face if polio were allowed to reemerge. Since 1988, more than 2 million children have been immunized, and it is estimated that as a result, 5 million fewer people have been paralyzed by polio. It is a testament to the success of the GPEI that worldwide cases of polio have fallen by over $99 \%$. Now is not the time to give up, even when the going seems to be getting tough. 